\title{
Modifications of phosphorus in Latosol as a function of humic acids and acidity
}

\author{
Márcia H. Beck ${ }^{1}$, Pedro A. V. Escosteguy ${ }^{2}$ \& Deborah P. Dick ${ }^{3}$ \\ ${ }^{1}$ Instituto Federal do Paraná. Foz do Iguaçu, PR. E-mail: marcia.beck@ifpr.br (Corresponding author) - ORCID: 0000-0002-4458-0751 \\ ${ }^{2}$ Universidade de Passo Fundo/Faculdade de Agronomia e Medicina Veterinária/Programa de Pós-graduação em Agronomia. Passo Fundo, RS. E-mail: \\ escosteguy@upf.br - ORCID: 0000-0001-8212-387X \\ ${ }^{3}$ Universidade Federal do Rio Grande do Sul/Instituto de Química/Departamento de Físico-Química. Porto Alegre, RS. E-mail: deborah.dick@ufrgs.br - \\ ORCID: 0000-0002-5615-8611
}

\section{Key words:}

phosphate

sorption

humic substances

\begin{abstract}
A B S T R A C T
The effect of humic acids (HA) on phosphorus (P) availability is still contradictory; thus, it is necessary to identify the conditions that play a crucial role in this effect. The aim of this study was to investigate the effect of HA application, combined with doses of $\mathrm{P}$, on the content of this nutrient in a Latosol with and without acidity correction. Two experiments were carried out, one with HA from peat and another with HA from mineral charcoal (leonardite). Doses of these acids (0; 1.12 and $5.62 \mathrm{mg} \mathrm{C} \mathrm{g}^{-1}$ of soil) and P (26.2 and $104.7 \mu \mathrm{g} \mathrm{P} \mathrm{g}^{-1}$ of soil, 1 and 4-fold higher than recommended, respectively) were tested at soil $\mathrm{pH} 4.5$ and 7.0, in a three-factorial design. The soil was incubated for 20 days and the soil-P content was measured by Mehlich-1 and remaining-P tests. The effect of HAs on $\mathrm{P}$ availability varied with the $\mathrm{P}$ doses and soil acidity. Humic acids application increases $\mathrm{P}$ content in Latosol when $\mathrm{P}$ dose is higher than recommended and there is no acidity correction ( $\mathrm{pH} 4.5$ ). However, there is no effect of HAs application on soil-P content when applying the recommended amount of this nutrient, irrespective of the $\mathrm{pH}$ value.
\end{abstract}

\section{Palavras-chave:}

fosfato

sorção

substâncias húmicas

\section{Modificações de fósforo em Latossolo em função de ácidos húmicos e acidez}

\begin{abstract}
R E S U M O
$\mathrm{O}$ efeito de ácidos húmicos $(\mathrm{AH})$ na disponibilidade de fósforo $(\mathrm{P})$ ainda é contraditório. Assim, é necessário identificar as principais condições que podem influenciar esse efeito. Com o trabalho, objetivou-se investigar o efeito da aplicação de $\mathrm{AH}$, combinada com doses de $\mathrm{P}$, no teor desse nutriente em Latossolo com e sem correção de acidez. Foram conduzidos dois experimentos, um com $\mathrm{AH}$ extraído de turfa e outro com $\mathrm{AH}$ extraído de carvão mineral (leonardita). Doses desses ácidos (0; 1,12 e 5,62 mg C g de solo) e de P (26,2 e 104,7 $\mu \mathrm{g} \mathrm{P} \mathrm{g}^{-1}$ de solo, 1 e 4 vezes maior que o recomendado, respectivamente) foram testadas, em dois valores de $\mathrm{pH}$ do solo $(4,5$ e 7,0), em esquema trifatorial. O solo foi incubado por 20 dias e os teores de $\mathrm{P}$ foram extraídos com os métodos Mehlich-1 e $\mathrm{P}$ remanescente. O efeito dos AHs na disponibilidade desse nutriente variou com as doses de $\mathrm{P}$ e o pH do solo. A adição desses ácidos aumenta o teor desse nutriente em latossolo somente quando a dose de correção de $\mathrm{P}$ for maior que a recomendada e a acidez ( $\mathrm{pH} 4,5)$ não for corrigida. Por outro lado, os AHs não influenciam o teor desse nutriente quando a dose de correção aplicada corresponder à quantidade recomendada, independentemente do $\mathrm{pH}$ do solo.
\end{abstract}




\section{INTRODUCTION}

Phosphorus $(\mathrm{P})$ is one of the most important nutrients to plants but it limits agricultural yield in tropical soils. Amorphous iron $(\mathrm{Fe})$ oxides in these soils form low-solubility complexes with phosphate, reducing the availability of this anion (Devau et al., 2011; Fink et al., 2014), which can also be influenced by humic acids (HAs) (Gerke, 2010). These interactions are surface phenomena which are influenced by various factors (Weng et al., 2012; Fink et al., 2014; Kleber et al., 2015).

Among the mechanisms of action of HAs, some of them reduce $P$ reaction with oxides, such as the blocking of adsorption sites (Kleber et al., 2015) and pores of the adsorbent (Kaiser \& Guggenberger, 2003), exchange of binders (Fu et al., 2013) and increase of negative charge density (Antelo et al., 2007). On the other hand, HAs can increase phosphate adsorption (Fu et al., 2013), dissolving Fe oxides and complexing this anion combined with this cation (Gerke, 2010). These mechanisms vary according to the type of HA and physical-chemical conditions of the medium, such as $\mathrm{pH}$, among other factors (Weng et al., 2012).

In general, the effect of HAs on $\mathrm{P}$ content have been reported in studies that use larger amounts than the recommended one to correct $\mathrm{P}$ deficiency in agricultural soils (Hua et al., 2008; Cessa et al., 2010). Besides being uneconomic, high $\mathrm{P}$ doses reduce the adsorption sites that retain this nutrient with greater energy (Guppy et al., 2005), which may lead to overestimation of the observed effects.

The effects of HAs on $\mathrm{P}$ content have also been evaluated in simple systems (solutions with Fe, HA and P oxides, without soil) (Antelo et al., 2007; Weng et al., 2012; Fu et al., 2013; Yan et al., 2016). Thus, there are uncertainties in relation to the effect of HAs addition on $\mathrm{P}$ availability, considering the conditions of application in soil and recommended doses of P. This study aimed to investigate the effect of HA application, combined with $\mathrm{P}$ doses, on the content of this nutrient in Latosol with and without acidity correction.

\section{Material ANd Methods}

Two experiments were simultaneously conducted at the Laboratory of Soil Chemistry and Fertility of the University of Passo Fundo (UPF), Passo Fundo, Rio Grande do Sul, Brazil ( $28^{\circ} 23^{\prime} 8.97^{\prime \prime}$ S; $52^{\circ} 32^{\prime} 16.70^{\prime \prime} \mathrm{W}$ ), in 2016. HA was extracted from peat in one experiment and from mineral charcoal (leonardite) in the other.

HAs were tested in a humic dystrophic Red Latosol collected in the 0-20 cm layer, in the UPF's experimental field. The soil had not been cultivated for the last 8 years (fallow) prior to the experiment. Before the experiment, the soil was analyzed according to Tedesco et al. (1995), and showed: $490.0 \mathrm{~g} \mathrm{~kg}^{-1}$ of clay, $110.0 \mathrm{~g} \mathrm{~kg}^{-1}$ of silt; $400.0 \mathrm{~g} \mathrm{~kg}^{-1}$ of sand; 4.5 of $\mathrm{pH}$ in water; 6.0 and $90 \mathrm{mg} \mathrm{kg}^{-1}$, of extractable $\mathrm{P}$ and $\mathrm{K}$ (Mehlich-1), respectively; $17.0 \mathrm{~g} \mathrm{~kg}^{-1}$ of organic carbon; 3.6, 1.6 and $0.8 \mathrm{cmol} \mathrm{kg}^{-1}$, of exchangeable $\mathrm{Al}$, $\mathrm{Ca}$ and $\mathrm{Mg}(1.0$ mol L-1 $\mathrm{KCl}$ ); $13.7 \mathrm{cmol}_{\mathrm{c}} \mathrm{kg}^{-1}$ of $\mathrm{H}+\mathrm{Al}$ (Potential acidity at $\mathrm{pH} 7.0$ ); and 48.0 and $18.0 \%$ of saturation by basic cations (V value) and $\mathrm{Al}$ in the effective $\mathrm{CEC}$, respectively.
Analysis of total contents of elements in the soil, determined by X-ray fluorescence (Bruker Ranger S2 EDFRX), indicated $0.14 \%\left(\mathrm{P}_{2} \mathrm{O}_{5}\right), 24.51 \%\left(\mathrm{Al}_{3} \mathrm{O}_{3}\right)$ and $11.68 \%\left(\mathrm{Fe}_{2} \mathrm{O}_{3}\right)$. Oxides and mineral composition were analyzed in an aliquot of soil, ground (agate mortar) and sieved $(0.50 \mathrm{~mm})$. Fe oxide content extracted with dithionite-citrate-sodium bicarbonate (Mehra \& Jackson, 1960) was $57.9 \mathrm{~g} \mathrm{~kg}^{-1}$, whereas Fe oxide content extracted with ammonium oxalate (Camargo et al., 2009) was $1.6 \mathrm{~g} \mathrm{~kg}^{-1}$.

Soil analysis by X-ray diffractometry (Bruker D2 Phaser diffractometer) with $\mathrm{CuKa}$ radiation, angle range from 3 to $60^{\circ}$, speed of $0.03^{\circ}$ at $1 \mathrm{~s}$ per step, and operation and voltage of $30 \mathrm{v}$ and $15 \mathrm{~mA}$, respectively, identified the following minerals (MINDAT, 2017): kaolinite (7.27 $)$ ), hematite (3.62; $2.71 ; 2.51$ and $2.20 \AA$ ), goethite (3.37 and $4.49 \AA$ ) and quartz (1.84 $\AA$ ). Maximum P adsorption capacity in the Latosol was determined at $\mathrm{pH} 4.5\left(0.64 \mathrm{mg} \mathrm{P} \mathrm{g}^{-1}\right)$ and $7.0\left(0.58 \mathrm{mg} \mathrm{P} \mathrm{g}^{-1}\right)$, using the Langmuir equation.

Peat HA was extracted in a peat bog in Arroio do Silva, Santa Catarina (29 $1^{\prime} 3.95^{\prime \prime}$ S; $\left.49^{\circ} 30^{\prime} 12.32^{\prime \prime} \mathrm{W}\right)$. Leonardite HA was obtained from the International Humic Substances Society (Lot 1S104H; IHSS, 2016). Total contents of carbon, hydrogen and nitrogen in the peat HA was determined in an Thermo Fisher Scientific elemental analyzer (Flash EA1112). $\mathrm{P}, \mathrm{S}, \mathrm{Fe}$ and $\mathrm{Mn}$ contents were extracted by nitric-perchloric digestion and determined by inductively coupled plasmaoptical emission spectrometry (Perkin Elmer Optima 8300 ICP-OES) (Table 1). The HAs used were selected for having different origins and chemical compositions, and also because leonardite is the most used HA in agriculture.

Treatments consisted of HA doses $\left(0,1.12\right.$ and $5.62 \mathrm{mg} \mathrm{C} \mathrm{g}^{-1}$ of soil) and $\mathrm{P}$ doses (26.2 and $\left.104.7 \mu \mathrm{g} \mathrm{g}^{-1}\right)$ in Latosol at two $\mathrm{pH}$ values (4.5 and 7.0). The lowest value corresponded to the $\mathrm{pH}$ of the soil collected in the field, whereas the highest value was obtained by applying calcium carbonate (analytical reagent, A.R.), three months before the experiment. In addition to these treatments, two controls were used (soil without and with $\mathrm{pH}$ correction and without $\mathrm{HA}$ application)

HA doses were 0, 2.37 and $11.87 \mathrm{mg} \mathrm{g}^{-1}$ (Peat HA) and $0,1.76$ and $8.82 \mathrm{mg} \mathrm{g}^{-1}$ (Leonardite HA). The lowest $\mathrm{P}$ dose is equivalent to the application of $120 \mathrm{~kg} \mathrm{P}_{2} \mathrm{O}_{5}$ ha $^{-1}(0-20 \mathrm{~cm})$, recommended for this soil based on the contents of $\mathrm{P}$ and clay. The highest $\mathrm{P}$ dose was tested to evaluate whether the application of an amount larger than recommended can overestimate the effect of HAs and is equivalent to $480 \mathrm{~kg} \mathrm{P}_{2} \mathrm{O}_{5} \mathrm{ha}^{-1}$.

Table 1. Total contents of some chemical elements of the peat and leonardite humic acids (HA) used in the experiments

\begin{tabular}{|c|c|c|}
\hline \multirow{2}{*}{ Element } & Peat HA & Leonardite $\mathrm{HA}^{3}$ \\
\hline & \multicolumn{2}{|c|}{ (\%) } \\
\hline Carbon & 47.39 & 63.81 \\
\hline Hydrogen & 4.89 & 3.70 \\
\hline Oxygen & $\mathrm{ND}^{1}$ & 31.27 \\
\hline Nitrogen & 1.67 & 1.23 \\
\hline Phosphorus & $<0.02$ & $<0.01$ \\
\hline $\mathrm{H} / \mathrm{C}$ & 0.103 & 0.058 \\
\hline Sulfur & 0.70 & 0.76 \\
\hline Iron & 0.38 & 0.25 \\
\hline Manganese & $<\mathrm{DL}^{2}$ & $<\mathrm{DL}$ \\
\hline
\end{tabular}

${ }^{1}$ Not determined; ${ }^{2}$ Lower than detection limit; ${ }^{3}$ Source: IHSS (2016) 
HAs and $\mathrm{P}$ were applied in the form of a solution. $\mathrm{P}$ doses were obtained by applying different volumes of stock solution (446 mg P L $\left.\mathrm{m}^{-1}\right)$, prepared with $\mathrm{KCl}\left(0.01 \mathrm{~mol} \mathrm{~L}^{-1}\right.$, in deionized water) and $\mathrm{KH}_{2} \mathrm{PO}_{4}$ (A.R., Merck). The tested HA doses were obtained by adding $\mathrm{KCl}$ solution $\left(0.01 \mathrm{~mol} \mathrm{~L}^{-1}\right.$, in deionized water) containing the necessary amounts of these acids. Treatments with the lowest $\mathrm{P}$ dose received the same stock solution used in treatments with the highest $\mathrm{P}$ dose, but the concentration of $\mathrm{P}$ was diluted using a $0.01 \mathrm{~mol} \mathrm{~L}^{-1} \mathrm{KCl}$ solution.

The experimental units ( $10 \mathrm{~g}$ of soil, dried and ground) were kept in polyethylene flasks and incubated in a temperaturecontrolled chamber $\left(23^{\circ} \mathrm{C}\right)$ for 20 days, after addition of the treatments. This incubation period was previously tested and is within the range used in studies that evaluate the effect of HAs in solutions with oxides. In 20 days, most of the P added is sorbed by the soil, but plant demand increases due to the exhaustion of the reserves of the seed or cotyledons. In this period, root system growth is still limited and it does not explore much the soil volume. These conditions are critical for P absorption and initial plant growth and, consequently, the effect of HAs after 20 days of incubation was considered to be important and was also evaluated.

Soil moisture was maintained at $70 \%$ of the maximum water retention capacity. After incubation, $\mathrm{P}$ contents extracted by Mehlich-1 (Mehlich-1 P) (Tedesco et al., 1995) and remaining in the equilibrium solution (Remaining $\mathrm{P}$ ) (Alvarez V. et al., 2000) were determined. The latter was obtained by adding $25 \mathrm{mg} \mathrm{L}^{-1}$ of $\mathrm{P}$ in solution with $0.01 \mathrm{~mol} \mathrm{~L}^{-1}$ $\mathrm{KCl}$ and the soil sample, and shaking it for $48 \mathrm{~h}$ at $23^{\circ} \mathrm{C}$. The analyses were performed in triplicate.

The experimental design was completely randomized and the treatments were tested with three replicates, in a threefactorial design (HA dose $\mathrm{x}$ P dose $\mathrm{x} \mathrm{pH}$ value). The results were subjected to analysis of variance and the means of HAs doses were compared by Tukey test $(\mathrm{p}<0.05)$, whereas the effect of $\mathrm{pH}$ was evaluated by $\mathrm{F}$ test $(\mathrm{p}<0.05)$.

\section{Results AND Discussion}

In both experiments, the results of the analysis of variance indicated that all parameters were influenced by the triple interaction between the tested factors $(\mathrm{pH}, \mathrm{P}$ doses and HA doses). In general, this was also observed with double interactions and all individual effects of these factors (Table 2).

Based on the analysis of variance, the individual effect of the tested factors was evaluated, revealing that Mehlich-1 $\mathrm{P}$ in the soil did not vary much between treatments in the experiments with both HAs (Figure 1). In treatments with the lowest $\mathrm{P}$ dose, the content of this nutrient was not influenced by these acids, increasing only with acidity correction. On the other hand, in treatments with highest $\mathrm{P}$ dose, HAs application influenced $\mathrm{P}$ content but this effect varied according to soil $\mathrm{pH}$ and type of HA applied.

In acid soil ( $\mathrm{pH} 4.5)$ and under highest $\mathrm{P}$ dose, the lowest HA dose $\left(2.37 \mathrm{mg} \mathrm{g}^{-1}\right)$ increased the content of this
Table 2. Probability of error in the analysis of variance for individual and combined effects of $\mathrm{pH}$, phosphorus $(\mathrm{P})$ doses and peat and leonardite humic acids (HA) doses on the contents of Mehlich-1 P and Remaining P of a Latosol

\begin{tabular}{|c|c|c|c|c|}
\hline \multirow{2}{*}{ Factor } & \multicolumn{2}{|c|}{ Peat HA } & \multicolumn{2}{|c|}{ Leonardite HA } \\
\hline & Mehlich-1 P & Remaining $\mathbf{P}$ & Mehlich-1 P & Remaining P \\
\hline $\mathrm{pH}$ & $\star \star$ & $\star \star$ & $\star \star$ & $\star \star$ \\
\hline$P$ & ** & $\star \star$ & $\star \star$ & $\star \star$ \\
\hline $\mathrm{HA}$ & * & $\star \star$ & * & ** \\
\hline $\mathrm{pH} \times \mathrm{P}$ & ** & ** & ** & ** \\
\hline $\mathrm{pH} \times \mathrm{HA}$ & ** & ns & ** & ** \\
\hline$P \times H A$ & ** & ** & $\star \star$ & ** \\
\hline $\mathrm{pH} \times \mathrm{P} \times \mathrm{HA}$ & ** & $\star \star$ & ** & $\star \star$ \\
\hline CV (\%) & 3.72 & 2.84 & 2.55 & 2.79 \\
\hline
\end{tabular}

${ }^{* *},{ }^{*}$, ns Probability of experimental error lower than 0.01 and 0.05 or higher than 0.05 , respectively; CV - Coefficient of variation

nutrient (Figure 1) by about 15.5 (peat) to $13 \%$ (leonardite), in comparison to the treatment without HA application, but under P application. In the soil with $\mathrm{pH}$ 7.0, HAs addition did not increase $\mathrm{P}$ content, even in treatments with the application of dose higher than the recommended one to correct $\mathrm{P}$ deficiency.

HAs did not influence Mehlich-1 P content in the treatments with the lowest $\mathrm{P}$ dose, possibly due to the low saturation of phosphate adsorption sites. Under such conditions, there is more binding energy of this anion to the functional groups of the adsorbents, which hampers the desorption (Guppy et al., 2005). In treatments with this $\mathrm{P}$ dose, the added amount of this nutrient $\left(26.0 \mu \mathrm{g} \mathrm{P} \mathrm{g}^{-1}\right)$ was 24 times lower than the maximum phosphate adsorption
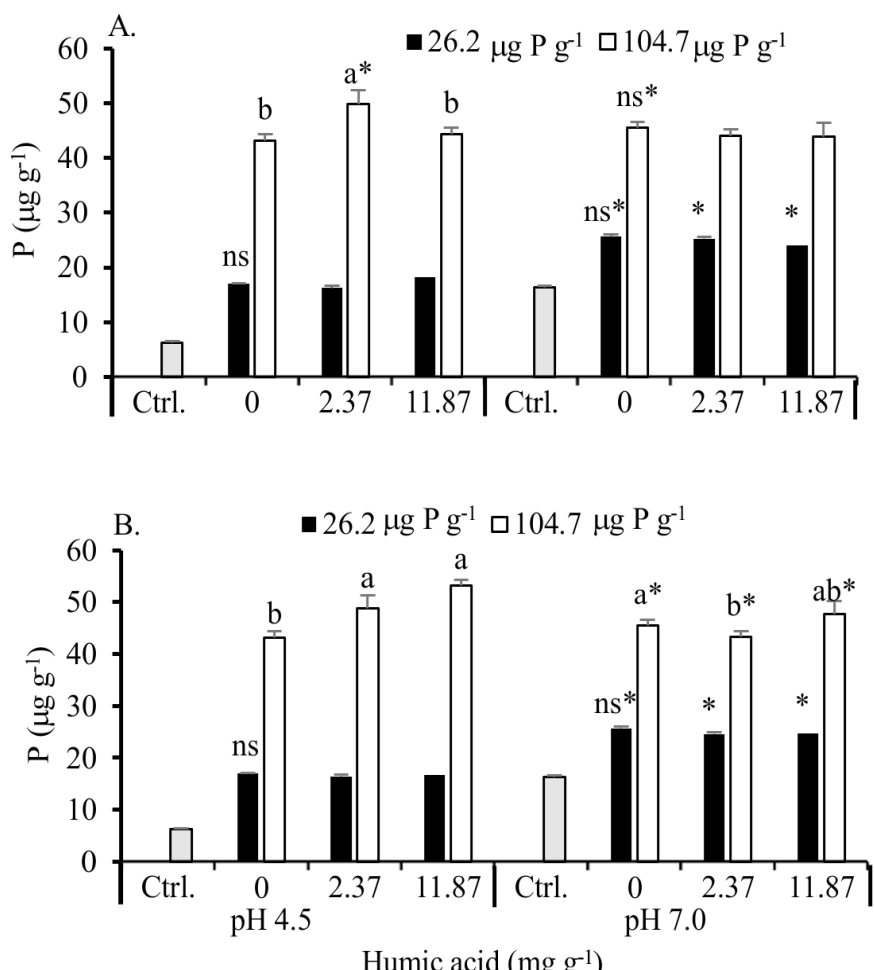

Different letters or ns - Means differ by Tukey test $(p<0.05)$, or do not differ, respectively, comparing humic acids doses at the same levels of $\mathrm{pH}$ and $\mathrm{P}$; *Effect of $\mathrm{pH}$ by $\mathrm{F}$ test, comparing treatments with equal doses of these acids and $\mathrm{P}$

Figure 1. Phosphorus (P) extracted with Mehlich-1 of Latosol incubated with doses of peat (A) and leonardite (B) humic acids and doses of $\mathrm{P}$, without $(\mathrm{pH} 4.5)$ and with $(\mathrm{pH} 7.0)$ acidity correction 
capacity of the Latosol with $\mathrm{pH}$ not corrected $\left(0.64 \mathrm{mg} \mathrm{P} \mathrm{g}^{-1}\right)$. On the other hand, with highest $\mathrm{P}$ dose $\left(107.4 \mu \mathrm{g} \mathrm{P} \mathrm{g}^{-1}\right)$ the added amount was six times lower than this capacity. Since the sites of higher binding energy of $\mathrm{P}$ to the adsorbents decrease as $\mathrm{P}$ saturation increases (Borggaard et al., 2005; Guppy et al., 2005; Cessa et al., 2010; Fu et al., 2013), this may have influenced the effects of HAs observed in the treatments with highest $\mathrm{P}$ dose.

In addition to the highest $\mathrm{P}$ dose, positive effect of HAs was observed only in soil with lower $\mathrm{pH}$. Although acidity increases phosphate adsorption, compromising the desorption of this anion, the positive action of fulvic acid on $\mathrm{P}$ desorption was also found in clay of Latosols with $\mathrm{pH} 4.5$ (Cessa et al., 2010), as observed in the present study.

Effect of HAs in acid soil may be related to the greater protonation of $\mathrm{Fe}$ oxides, present in more $\left(57.9 \mathrm{~g} \mathrm{~kg}^{-1}\right)$ and less $\left(1.6 \mathrm{~g} \mathrm{~kg}^{-1}\right)$ crystalized forms. The point of zero charge of these oxides varies from pH 7.5 to 9.5 (Borggaard et al., 2005; Antelo et al., 2007), indicating that in acid soil the functional groups of these adsorbents were protonated.

Oxide protonation favors the maintenance of negative charges in the functional groups of the HAs, due to the reduction in the number of bonds between these groups and $\mathrm{H}^{+}$, increasing the repulsion of the organic molecules (Gerke, 2010). Such condition favors the interaction of HAs with other soil constituents, such as Fe oxides, and consequently can favor phosphate desorption. Conversely, in soil with higher $\mathrm{pH}$, the higher $\mathrm{Ca}$ content, resulting from the application of carbonate, favored phosphate adsorption (Weng et al., 2012). According to these authors, this results from the electrostatic interaction (attraction) between these ions, which increases in soil with higher $\mathrm{pH}$ and humic substances, a condition in which $\mathrm{Ca}$ adsorption, and consequently $\mathrm{P}$ adsorption, also increases.

Correction of soil $\mathrm{pH}$ increased the $\mathrm{P}$ content extracted by Mehlich-1 (50\% increment) in both experiments (Figure 1A and $\mathrm{B}$ ). This effect is mainly due to the insolubilization of Fe and Al oxides (Devau et al., 2011). These oxides react with the hydroxyl generated by Ca carbonate, forming species that are less soluble and, therefore, less reactive with the phosphate.

It is worth pointing out that, although the tested $\mathrm{pH}$ values were important to contrast the effect of HAs under conditions with ( $\mathrm{pH} 4.5)$ and without ( $\mathrm{pH}$ 7.0) acidity, caution must be taken in extrapolating the results because the $\mathrm{pH}$ values of cultivated soils vary according to crop group and may not correspond to the tested values. $\mathrm{pH}$ values lower than 5.0 can prevail in some specific crops, such as yerba mate, eucalyptus, Pinus, cassava and natural pasture. On the other hand, $\mathrm{pH}$ values $>6.5$ are typical of alfalfa, asparagus, olive tree, among others. Nevertheless, additional studies should be conducted to evaluate the effects of HAs on P contents in soils cultivated with other crops, especially those for which the adequate $\mathrm{pH}$ range is from 5.5 to 6.0 , typical of tropical agricultural soils, with correction of acidity.

Based on the observation that HAs application increased Mehlich-1 P content only when $\mathrm{P}$ dose was 4 times higher than recommended and in acid soil (Figure 1), the Remaining $\mathrm{P}$ content was evaluated to confirm this effect. The condition of high $\mathrm{P}$ dose is inherent to the Remaining $\mathrm{P}$ determination method (Alvarez V. et al., 2000), which consists in applying a concentrated solution of $\mathrm{P}$ (in this study, $25 \mathrm{mg} \mathrm{P} \mathrm{L}^{-1}$ or $573 \mathrm{~kg} \mathrm{P}_{2} \mathrm{O}_{5} \mathrm{ha}^{-1}$ ). This amount of $\mathrm{P}$ was added to the soil already containing the amounts applied to test the doses of this nutrient (26 and $107 \mu \mathrm{g} \mathrm{P} \mathrm{g}^{-1}$ or 120 and $480 \mathrm{~kg} \mathrm{P}_{2} \mathrm{O}_{5}$ ha $^{-1}$, respectively).

In the soil with $\mathrm{pH} 4.5$, the Remaining $\mathrm{P}$ content increased with the highest HA dose and at both $\mathrm{P}$ doses (Figure 2). This effect contrasts with that observed on the Mehlich-1 P content, which only increased in treatments with highest $\mathrm{P}$ dose (Figure 1).

Effect of HAs on Remaining $\mathrm{P}$ content also occurred in the soil with pH 7.0 (Figure 2), which was not observed in the Mehlich-1 P content either (Figure 1). In the soil with corrected acidity, peat HA increased the Remaining P content in the treatments in which both $\mathrm{P}$ doses were tested (Figure 2A), whereas leonardite HA only increased in the treatment with highest $\mathrm{P}$ dose (Figure 2B), suggesting different mechanisms of action of these acids.

In the acid soil with HA addition, the increments in Remaining P content were higher than those of Mehlich-1 P. Whereas this latter varied from 13 to $15 \%$, depending on the type of HA applied, the increments in Remaining $\mathrm{P}$ varied from 29 to $42 \%$ (peat HA) and from 8 to 55\% (leonardite $\mathrm{HA}$ ). Increase in Remaining P was expected in the treatments with higher $\mathrm{P}$ dose, because Mehlich-1 $\mathrm{P}$ increased with the addition of HAs when the P dose was high. On the other hand, the increase of Remaining $\mathrm{P}$ in treatments with lowest $\mathrm{P}$ dose is related to the addition of the solution containing $\mathrm{P}$ used in
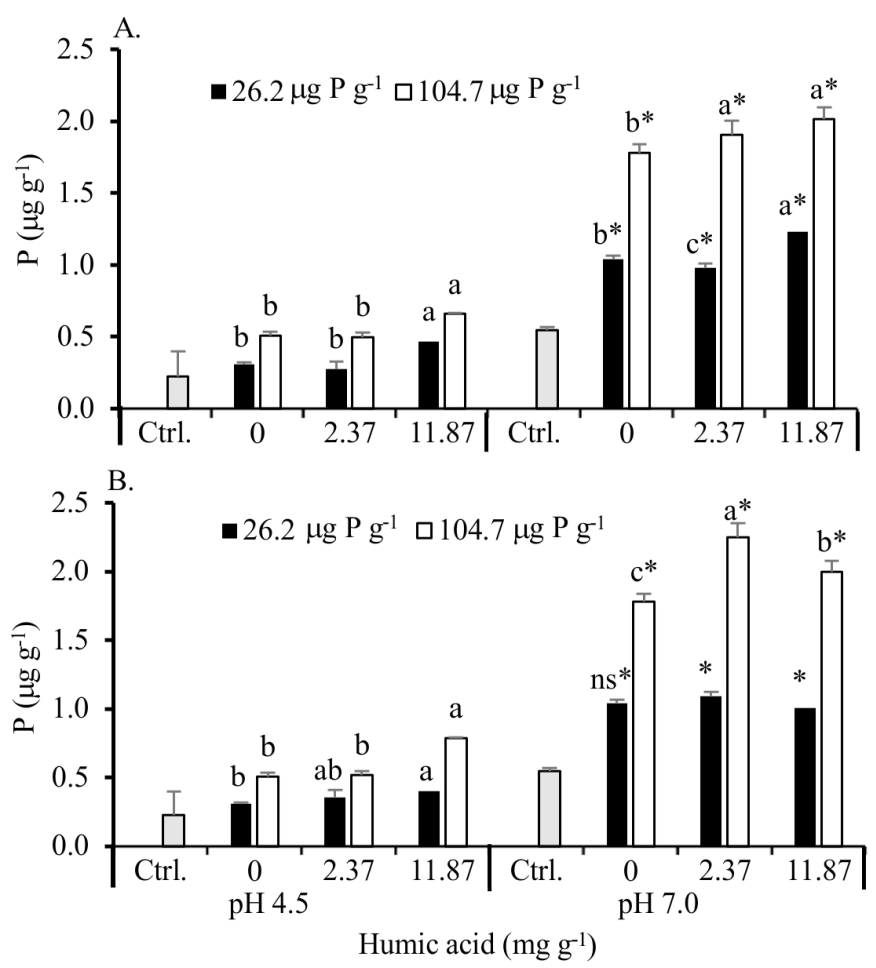

Different letters or $n s-$ Means differ by Tukey test $(p<0.05)$, or do not differ, respectively, comparing humic acids doses at the same levels of $\mathrm{pH}$ and $\mathrm{P}$; *Effect of $\mathrm{pH}$ by $\mathrm{F}$ test, comparing treatments with equal doses of these acids and $\mathrm{P}$

Figure 2. Content of Remaining phosphorus $(P)$ in the equilibrium solution of Latosol incubated with doses of peat (A) or leonardite (B) humic acids and doses of $\mathrm{P}$, without $(\mathrm{pH} 4.5)$ and with ( $\mathrm{pH} 7.0)$ acidity correction 
this method, equivalent to $125 \mu \mathrm{g} \mathrm{P} \mathrm{g}{ }^{-1}$ of soil. The sum of this amount with the initially applied $\mathrm{P}$ doses is equivalent to $\mathrm{P}$ values 5.8 times (lowest dose) and 8.9 times (highest doses) higher than the recommended dose to correct the soil used, i.e., uneconomic doses in agricultural systems.

The high amounts of $\mathrm{P}$ applied with the Remaining $\mathrm{P}$ determination method increased the saturation of phosphate adsorption sites, reducing the binding energy of this anion with the adsorbent, which may have favored the effect of HAs. Thus, these results should be interpreted carefully and contextualized with this condition. Compared with the results for Mehlich-1 P (Figure 1), the results for Remaining $\mathrm{P}$ demonstrate that the positive effect of HAs addition (Figure 2) was favored by the large amount of $P$ applied to the soil. This condition also promoted the positive effect of HAs in the soil with acidity correction, unlike the result found in treatments with the $\mathrm{P}$ dose recommended to correct $\mathrm{P}$ deficiency (Figure 1).

\section{Conclusions}

1. Addition of peat and leonardite humic acids increases the content of available phosphorus in Latosol only when the dose to correct $\mathrm{P}$ deficiency is higher than recommended and acidity is not corrected ( $\mathrm{pH} 4.5$ ).

2. Addition of peat and leonardite humic acids does not influence the content of available phosphorus in Latosol when the dose to correct $\mathrm{P}$ deficiency corresponds to the recommended one, irrespective of acidity correction ( $\mathrm{pH} 4.5$ or 7.0$)$.

\section{Literature Cited}

Alvarez V., V. H.; Novais, R. F.; Dias, L. E.; Oliveira, J. A. de. Determinação e uso do fósforo remanescente. Boletim Informativo da Sociedade Brasileira de Ciência do Solo, v.25, p.27-32, 2000.

Antelo, J.; Arce, F.; Avena, M.; Fiol, S.; López, R.; Macías, F. Adsorption of a soil humic acid at the surface of goethite and its competitive interaction with phosphate. Geoderma, v.138, p.1219, 2007. http://dx.doi.org/10.1016/j.geoderma.2006.10.011

Borggaard, O. K.; Raben-Lange, B.; Gimsing, A. L.; Strobel, B. W. Influence of humic substances on phosphate adsorption by aluminium and iron oxides. Geoderma, v.127, p.270-279, 2005. https://doi.org/10.1016/j.geoderma.2004.12.011

Camargo, O. A.; Moniz, A. C.; Jorge, J. A.; Valadares, J. M. A. S. Métodos de análise químicos, mineralógicos e física de solos do Instituto Agronômico de Campinas. Campinas: IAC, 2009. 77p. Boletim Técnico, 106

Cessa, R. M. A.; Vitorino, A. C. T.; Celi, L.; Novelino, J. O.; Barberis, E. Adsorção de fósforo em frações argila na presença de ácido fúlvico. Revista Brasileira de Ciência do Solo, v.34, p.1535-1542, 2010. http://dx.doi.org/10.1590/S0100-06832010000500006
Devau, N.; Hinsinger, P.; Cadre, E. le; Colomb, B.; Gérard, F. Fertilization and $\mathrm{pH}$ effects on processes and mechanisms controlling dissolved inorganic phosphorus in soils. Geochimica et Cosmochimica Acta, v.75, p.2980-2996, 2011. http://dx.doi. org/10.1016/j.gca.2011.02.034

Fink, J. R.; Inda, A. V.; Bayer, C.; Torrent, J.; Barrón, V. Mineralogy and phosphorus adsorption in soils of south and central-west Brazil under conventional and no-tillage systems. Acta Scientiarum. Agronomy, v.36, p.379-387, 2014. http://dx.doi.org/10.4025/ actasciagron.v36i3.17937

Fu, Z.; Wu, F.; Song, K.; Lin, Y.; Bai, Y.; Zhu, Y.; Giesy, J. P. Competitive interaction between soil-derived humic acid and phosphate on goethite. Applied Geochemistry, v.36, p.125-131, 2013. https:// doi.org/10.1016/j.still.2015.07.017

Gerke, J. Humic (organic matter)-Al(Fe)-phosphate complexes: An underestimated phosphate form in soils and source of plantavailable phosphate. Soil Science, v.175, p.417-425, 2010. https:// doi.org/10.1097/SS.0b013e3181f1b4dd

Guppy, C. N.; Menzies, N. W.; Moody, P. W.; Blamey, F. P. C. Competitive sorption reactions between phosphorus and organic matter in soil: A review. Australian Journal of Soil Research, v.43, p.189-202, 2005. https://doi.org/10.1071/SR04049

Hua, Q.-X.; Li, J.-Y.; Zhou, J.-M.; Wang, H.-Y.; Du, C.-W.; Chen, X.Q. Enhancement of phosphorus solubility by humic substances in Ferrosols. Pedosphere, v.18, p.533-538, 2008. https://doi. org/10.1016/S1002-0160(08)60044-2

IHSS - International Humic Substances Society. Products. Available on: <http://www.ihss.eua>. Access on: Aug. 2016.

Kaiser, K.; Guggenberger, G. Mineral surfaces and soil organic matter. European Journal of Soil Science, v.54, p.219-236, 2003. https://doi.org/10.1046/j.1365-2389.2003.00544.x

Kleber, M.; Eusterhues, K.; Keiluweit, M.; Mikutta, C.; Mikutta, R.; Nico, P. S. Mineral-organic associations: Formation, properties, and relevance in soil environments. Advances in Agronomy, v.130, p.1-140, 2015. https://doi.org/10.1016/ bs.agron.2014.10.005

Mehra, O. P.; Jackson, M. L. Iron oxide removal from soils and clays by dithionite-citrate system buffered with sodium bicarbonate. In: National Conference on Clays and Clay Minerals, 7, 1960. Proceedings... New York: Pergamon, 1960. p.317-332.

MINDAT - Mineralogy Database. 2017. Available on: <http://www. mindat.org>. Access on: Aug. 2017.

Tedesco, M. J.; Gianello, C.; Bissani, C. A. Bohnen, H.; Volkweis, S. J. Análise de solo, planta e outros materiais. 2.ed. Porto Alegre: Universidade Federal do Rio Grande do Sul, 1995. 174p.

Weng, L.; Riemsdijk, W. H. van; Hiemstra, T. Factors controlling phosphate interaction with iron oxides. Journal of Environmental Quality, v.41, p.628-635, 2012. http://dx.doi.org/10.2134/ jeq2011.0250

Yan, J.; Jiang, T.; Yao, Y.; Lu, S.; Wang, Q.; Wei, S. Preliminary investigation of phosphorus adsorption onto two types of iron oxide-organic matter complexes. Journal of Environmental Sciences, v.42, p.142162, 2016. https://doi.org/10.1016/j.jes.2015.08.008 